\title{
Nutrient uptake and growth characteristics of nitrogen fertigated sweet peppers under drip irrigation and plastic mulch'
}

\author{
Manuel Crespo-Ruiz, Megh R. Goyal, \\ Carmela Chao de Báez and Luis $E$. Rivera ${ }^{2}$
}

\begin{abstract}
In the semiarid southern coast of Puerto Rico at the Fortuna agricultural experiment substation, Juana Diaz, we conducted a study on N, P and $K$ uptake by nitrogen fertigated sweet peppers (ev. Cubanelle) and growth parameters (fresh and dry weight of plant, fresh and dry weight of fruit). The treatments were $\mathrm{T1}=500, \mathrm{T2}=300$ and $\mathrm{T3}=150 \mathrm{~kg}$ of $\mathrm{N}$ per hectare in 11 applications via drip irrigation, $T 4=500 \mathrm{~kg}$ of N/ha banded, TS = control, replicated four times in a complete randomized split plot design. Nitrogen source was urea. The subplots were used for plastic mulched and nonmulched plots. The relationships between $N, P, K$ and growth parameters versus days after transplanting were determined by the equation $Y=A /\left(B+(C-X)^{2}\right.$, a Mitscherlich curve type. These relationships indicated 5 phases of nutrient uptake. Coefficient of determination varied from 0.55 to 0.85 for growth parameters and from 0.70 to 0.99 for nutrient uptake. Nutrient uptake values were significantly higher in the last one-third of the growing cycle. The commercial pepper yield was 46.8 , $51.2,43.1,31.0$ and 20.8 tons/ha with plastic mulching compared with $26.2,34.6,27.9,25.9$ and 14.8 tons/ha with no mulching in the I1, T2, T3, T4 and T5 plots, respectively. Fertigation with $300 \mathrm{~kg} / \mathrm{ha}$ of $\mathrm{N}$ produced a higher commercial yield compared with fertilization and contral at $\mathbf{P}=$ 0.05 . Plastic mulching increased pepper yield significantly over that with no mulching of $P=0.05$.
\end{abstract}

\section{RESUMEN}

Absorción de nutrimentos y características del desarrollo de pimientos abonados con nitrógeno en el agua de riego por goteo

Un estudio sobre la absorción de $N_{s}, P, K$ en pimientos (cv, Cubanelle) abonados con urea y los parámetros de crecimiento (pesos húmedo y seco

${ }^{1}$ Manuseript submitted to Editorial Board 16 October 1987.

This study was conducted under Southeast Regional Project S-143 (H-326), "Trickle Irrigation in Humid Regions-Puerto Rico". This contribution is partly based on a MS Thesis submitted by the Senior author in the Graduate School of the University of Puerto Rico, Mayaguez Campus, in partial fulfillment of the requirements of the degree of Master in Science in the Faculty of Agronomy and Soils - 1986. The authors thank Jose BadilloFelieiano, Luis M. Cruz Pérez and Oscar Muñiz for their valuable suggestions.

"Graduate Student, Associate Agricultural Engineer, Associate Statistician and Research Assistant, Agricultural Experiment Station, University of Puerto Rico, Mayagiez Campus, Río Piedras, P. R. 
de las plantas y las frutas) se realizó en la costa sur semiárida de Puerto Rico en el Centro de Investigación y Desarrollo de Fortuna. Los tratamientos fueron $\mathrm{T1}=100 \% \mathrm{~N}, \mathrm{T2}=\mathrm{N}, \mathrm{T} 3=30 \% \mathrm{~N}$ en 11 aplicaciones de riego por goteo, $\mathrm{T4}=100 \% \mathrm{~N}$ aplicado en franjas, $\mathrm{T5}=$ control sin urea, repefido cuatro veces en un diseño de parcelas completamente aleatorizadas. Los subtratamientos fueron con y sin cubierta plástica. La relación entre $\mathbf{N}, \mathbf{P}, \mathrm{K}, \mathrm{Ca}, \mathrm{Mg}$ y los parámetros de crecimiento contra los días después del trasplante fueron $Y=A\left(B+(C-X)^{2}\right)$ y fueron del tipo de la curva de Mitscherlich. Esta relación indicó 5 fases de absorción de nutrimentos. El coeficiente de determinación varió de 0.55 a 0.85 para los parámetros de crecimiento y de 0.70 a 0.99 para la absorción de nutrimentos. El uso de cubierta plástica y el abonado de $300 \mathrm{~kg}$. $/$ ha. de $\mathbf{N}$ produjeron valores significativamente altos en los componentes de crecimiento al compararlo con los demás tratamientos. El rendimiento comercial fue significativamente más alto con los tratamientos de abono disuelto en el riego por goteo que el abonado en franjas (T4) y el tratamiento testigo (T5). El uso de cubierta plástica aumentó el rendimiento del pimiento significtivamente al compararse con el trafamiento sin cubierta.

\section{INTRODUCTION}

Fertigation is the application of soluble fertilizers via drip irrigation systems and is one of the latest and fastest growing technologies in agriculture (5). Fertigation advantages are improved efficiency of fertilizer use, minimal leaching losses, optimal nutritional balance by supplying the nutrients directly to the root zone $(1,7)$, control of nutrient concentration in soil solution, savings in labor and energy, and flexibility in scheduling in relation to crop demand. Drip irrigation calls for a complete fertigation schedule to provide adequate nutrients to the plant (7). Fertilizer applied via drip irrigation must be soluble to avoid precipitation and clogging of drip lines. Goldberg et al. (3) found that nitrate applied via drip irrigation remained within the wetting zone around the root system of the plant. Santiago and Goyal (7) found that Mitscherlich curve type relationships described nutrient uptake by peppers and growth parameters versus days after transplanting in different plastic mulched plots. Goyal et al. (5) found exponential relationships among pepper growth parameters versus days after transplanting in different plastic mulched plots.

The objectives of this study were to compare the effects of three nitrogen fertigation rates $(\mathrm{T} 1=100 \%, \mathrm{~T} 2=60 \%$ and $\mathrm{T} 3=30 \% \mathrm{~N})$ with fertilization rates ( $\mathrm{T} 4100 \%$ of $\mathrm{N}$ banded) and no fertilization on growth parameters and nutrient uptake by irrigated sweet peppers under plastic mulch. The soil belongs to the San Antón series, with a pH of 7.9.

\section{MATERIALS AND METHODS}

This study was conducted in a San Antón soil (fine loamy, montmorillonitic, isohyperthermic, Cumulic Haplustolls, with a $\mathrm{pH}$ of 7) at the Fortuna agricultural experiment substation, Juana Díaz, P. R., located in the semiarid southern coast of Puerto Rico. The conductivity of the 
soil solution is $0.21 \mathrm{mmhos}$ per $\mathrm{cm}$. Chemical analysis of soil (2) indicated $22 \mathrm{meq} / 100 \mathrm{~g}$ of cation exchange capacity, $1.71 \mathrm{p} / \mathrm{m} \mathrm{P}, 694.4 \mathrm{p} / \mathrm{m} \mathrm{K}, 494.4$ $\mathrm{p} / \mathrm{m} \mathrm{Mg}$, and $5386 \mathrm{p} / \mathrm{m}$ Ca. Four-week-old pepper transplants (Capsicum annuum L. cv. Cubanelle) were planted 17 December, $1983,15 \mathrm{~cm}$ away from the dual chamber drip line (4) and on both sides of drip line at 30 $\mathrm{cm}$ spacing within the row. The beds were spaced $1.8 \mathrm{~m}$ apart. The fertigation treatments were $\mathrm{T} 1=30 \mathrm{~g}, \mathrm{~T} 2=18 \mathrm{~g}$, and $\mathrm{T} 3=9 \mathrm{~g}$ of urea per plant $(\mathrm{T} 1=500, \mathrm{~T} 2=300$ and $\mathrm{T} 3=150 \mathrm{~kg}$ of $\mathrm{N} / \mathrm{ha})$ applied via drip irrigation system in 11 applications on days $6,13,17,27,34,42,50$, $56,65,79$ and 95 after transplanting; $\mathrm{T} 4=15 \mathrm{~g}$ urea per plant $(500 \mathrm{~kg}$ $\mathrm{N} / \mathrm{ha}$ ) sidedressed on days 6 and 56 ; and $\mathrm{T} 5=$ control, $0.0 \mathrm{~g} \mathrm{~N}$ per plant. These treatments were replicated four times in a complete randomized split-plot block design. Split plots were used to evaluate effects of silvercoated plastic mulching (P) and no mulching (NP).

Two plants randomly chosen from each plot were cut at the soil surface on days $25,35,42,49,56,63,70,77,84,91,98,105$ and 112 after transplanting to evaluate plant fresh and dry weight and fruit fresh and dry weight. These were oven dried for 48 hours at $70^{\circ} \mathrm{C}$. Dry samples were chopped and ground, and analyzed for N, P and K. Nitrogen was determined by the $\mathrm{Kjeldahl}$ macromethod; $\mathrm{P}$ by the $\mathrm{L}$ - ascorbic acid + $\mathrm{NH}_{4} \mathrm{MO}+\mathrm{H}_{2} \mathrm{SO}_{4}+$ antimony potassium tartrate method; and $\mathrm{K}$ by flame photometry (2).

\section{RESULTS AND DISCUSSION}

A Mitscherlich type equation $\mathrm{Y}_{1,2}=\mathrm{A} /\left[1+\mathrm{B} \times(\mathrm{C}-\mathrm{X})^{2}\right]$ where, $\mathrm{Y}_{1}=$ growth parameter (g/plant); $\mathrm{Y}_{2}=$ nutrient uptake (mg/plant); X $=$ days after transplanting; $\mathrm{A}, \mathrm{B}, \mathrm{C}=$ regression coefficients fitted better to the data compared to linear relationship.

Table 1 indicates pepper growth parameters (fresh and dry plant weight, fresh and dry fruit weight) versus days after transplanting. The relationships were of sigmoidal type (5). All regression coefficients were significant at the $5 \%$ level. Coefficient of determination $\left(R^{2}\right)$ varied from 0.55 to 0.85 . In the relationships among dry plant weight versus days after transplanting, figure 1 reveals heavier plants in the fertigated plots than in the control plots.

In all treatments and subtreatments relationships among $N, P, K$ uptake versus days after transplanting were of Mitscherlich type as figure 2 to 4 indicate. The regression coefficients were significant at the $5 \%$ level. The coefficient of determination varied from 0.70 to 0.99 . The nutrient uptake values in the T2 plots were higher than those in T4 plots because pepper transplants were able to take up nutrients efficiently when nitrogen fertigated weekly. All these curves exhibited the five nutrient-uptake phases, namely a lag phase (plants are being established), a $\log$ phase (nutrient uptake continues at logarithmic rate), a 
TABLE 1.-Relationship between growth parameters and days after transplanting in urea fertigated sweet peppers (var. Cubanelle) under drip irrigation.

Date of transplanting: December 17, 1983; Date of last harvest: April 4, 1984

\begin{tabular}{|c|c|c|c|c|c|c|c|c|c|}
\hline \multirow[b]{3}{*}{$\begin{array}{l}\text { Growth } \\
\text { Parameter }\end{array}$} & \multicolumn{9}{|c|}{ Regression coefficients ${ }^{e}$} \\
\hline & \multirow[b]{2}{*}{ Treatment ${ }^{1}$} & \multicolumn{3}{|c|}{ Plastic mulch (P) } & \multicolumn{4}{|c|}{ No plastic muleh (NP) } & \multirow[b]{2}{*}{$\mathbf{R}_{z}$} \\
\hline & & A & B & C & $\mathrm{R}_{2}$ & A & B & $\mathrm{C}$ & \\
\hline \multirow{5}{*}{$\begin{array}{l}\text { Plant fresh } \\
\text { weight } \\
(\mathrm{X}=2 \text { to } 112)\end{array}$} & T1 & 251.6 & 0.001 & 102.1 & 0.55 & 192.4 & 0.001 & 95.3 & 0.65 \\
\hline & $\mathrm{T} 2$ & 294.3 & 0.001 & 94.9 & 0.59 & 198.9 & 0.001 & 107.8 & 0.45 \\
\hline & T3 & 262.4 & 0.001 & 105.2 & 0.79 & 180.3 & 0.001 & 103.6 & 0.77 \\
\hline & $\mathrm{T} 4$ & 141.6 & 0.001 & 92.2 & 0.45 & 176.6 & 0.001 & 94.1 & 0.76 \\
\hline & T5 & 170.3 & 0.001 & 104.5 & 0.59 & 143.3 & 0.001 & 112.9 & 0.67 \\
\hline \multirow{5}{*}{$\begin{array}{l}\text { Plant dry } \\
\text { weight } \\
(X=2 \text { to 112) }\end{array}$} & $\mathrm{T1}$ & 43.4 & 0,001 & 103.5 & 0.75 & 33.9 & 0.001 & 98.7 & 0.72 \\
\hline & $\mathrm{T} 2$ & 54.2 & 0.001 & 94.9 & 0.63 & 36.5 & 0.001 & 106.1 & 0.57 \\
\hline & T3 & 47.0 & 0.001 & 104.2 & 0.76 & 33.6 & 0.001 & 103.3 & 0.85 \\
\hline & T4 & 27.8 & 0.002 & 91.2 & 0.62 & 32.5 & 0.001 & 37.1 & 0.82 \\
\hline & T5 & 29.8 & 0.001 & 103.9 & 0.65 & 26.7 & 0.001 & 112.4 & 0.75 \\
\hline \multirow{5}{*}{$\begin{array}{l}\text { Fruit fresh } \\
\text { weight } \\
\text { (X }=42 \text { to 112) }\end{array}$} & $\mathrm{T} 1$ & 980.4 & 0.002 & 99.9 & 0.71 & 693.5 & 0.003 & 93.4 & 0.66 \\
\hline & $\mathrm{T} 2$ & 1212.5 & 0.002 & 97.5 & 0.74 & 643.6 & 0.002 & 98.8 & 0.68 \\
\hline & T3 & 989.0 & 0.002 & 101.5 & 0.78 & 622.7 & 0.002 & 99.6 & 0.83 \\
\hline & $\mathrm{T} 4$ & 973.1 & 0.001 & 105.1 & 0.70 & 637.3 & 0.002 & 95.7 & 0.81 \\
\hline & T5 & 672.5 & 0.003 & 101.4 & 0.62 & 414.4 & 0.002 & 101.4 & 0.59 \\
\hline \multirow{5}{*}{$\begin{array}{l}\text { Fruit dry } \\
\text { weight } \\
(\mathrm{X}=42 \text { to } 112)\end{array}$} & $\mathrm{T} 1$ & 75.8 & 0.002 & 96.9 & 0.68 & 54.9 & 0.003 & 98.4 & 0.69 \\
\hline & $\mathrm{T} 2$ & 93.8 & 0.003 & 94.6 & 0.73 & 54.1 & 0.003 & 96.6 & 0.65 \\
\hline & T3 & 76.0 & 0.003 & 96.5 & 0.79 & 47.3 & 0.002 & 97.5 & 0.81 \\
\hline & $\mathrm{T} 4$ & 74.0 & 0.002 & 97.9 & 0.73 & 54.4 & 0.003 & 95.2 & 0.85 \\
\hline & T5 & 54.7 & 0.003 & 100.4 & 0.64 & 36.8 & 0.003 & 96.5 & 0.67 \\
\hline
\end{tabular}


The treatments were $\mathrm{T} 1=30 \mathrm{~g}, \mathrm{~T} 2=18 \mathrm{~g}, \mathrm{~T} 3=9 \mathrm{~g}$ urea per plant applied via drip irrigation in 11 equal applications on days $6,13,17,24$, $34,42,50,56,65,79,95$ after transplanting; $\mathrm{T} 4=15 \mathrm{~g}$ urea per plant sidedressed on days 6 and $56 ;$ and $\mathrm{T} 5=0.0 \mathrm{~g}$ urea per plant. $\mathrm{T}=$ average of all treatments, $\mathbf{P}=$ Silver coated black plastic mulch and NP $=$ no plastic.

"All regression coefficients were significant at the $5 \%$ level of significance.

$\mathrm{Y}=\mathrm{A} /\left(\mathbf{1}+\mathrm{B}(\mathrm{C}-\mathrm{x})^{2}\right)$, where, $\mathrm{Y}=$ growth parameter $(\mathrm{g}$ per plant);

$\mathrm{X}=$ days after transplanting;

$\mathrm{A}, \mathrm{B}, \mathrm{C}=$ regression coefficients;

$\mathrm{R}^{2}=$ coefficient of determination. 


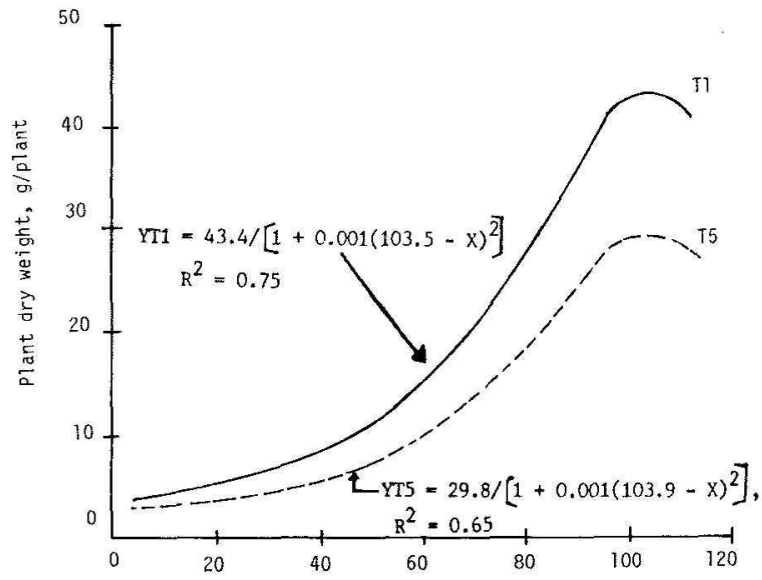

Days after transplanting, $X$

FIG. 1.-Dry weight of pepper plant versus days after transplanting. $\mathrm{T} 1=100 \%$ nitrogen via drip irrigation, $\mathrm{T} 5=$ control.

decreasing rate (nutrient uptake is decreasing but plant still continues to extract the nutrients), a point at which the nutrient uptake is maximum, and a senescence phase. The greatest amount of nutrient uptake occurred during the last three phases. These results agree with those of Santiago and Goyal (7) and Lorenz and Maynard (6). Nutrient uptake order was $\mathrm{K}>\mathrm{N}>\mathrm{Ca}>\mathrm{Mg}>\mathrm{P}$ in $\mathrm{T} 2$ plots with plastic mulch. On the 98th day nitrogen uptake was 3390, 3915, 2785, 2659, $2289 \mathrm{mg} /$ (plant + fruit) in the T1, T2, T3, T4, T5 plots with plastic mulching; 1975, 2338, 2101, 2344 and $1642 \mathrm{mg} /$ (plant + fruit) in the T1, T2, T3, T4, T5 plots with no mulching, respectively.

Table 2 shows commercial yield of sweet peppers. Fertigation of nitrogen (T1, T2, T3) significantly outyielded fertigation (T4) and control (T5) at $P=0.05$. Plastic mulch increased yield significantly at $P=0.05$ over that with non-mulching. Increasing fertigation rate from 300 to 500 $\mathrm{kg}$ N/ha did not increase yield. These results agree with those of Santiago and Goyal (7). This study indicates that plastic mulching can increase pepper yield because of favorable micro climate around the plant in the 


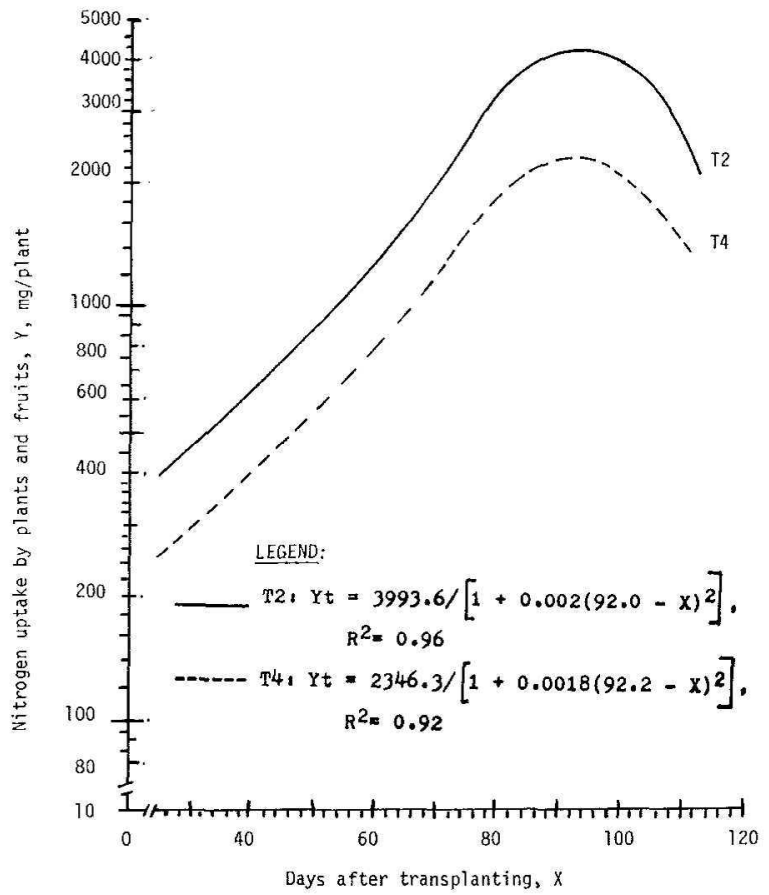

FiG. 2.-Nitrogen uptake by drip irrigated pepper plants in silver coated blaek plastie mulched plots. $\mathrm{T} 2=60 \% \mathrm{~N}$ via drip irrigation and $\mathrm{T} 4=$ banded nitrogen. Each observation is a mean of four observations.

winter. The interaction between plastic mulch and $\mathrm{N}$ levels were significant at $5 \%$. This study recommends fertigation rate of $300 \mathrm{~kg}$ N/ha in 12 weekly applications and use of silver coated plastic mulching in sweet peppers (var. Cubanelle). Fertigation should be initiated when the soil around the dripper is at field capacity. Flushing time should be enough to allow time ratio of not more than 0.8 . Rule of thumb is to fertigate during middle third of irrigation cycle. 


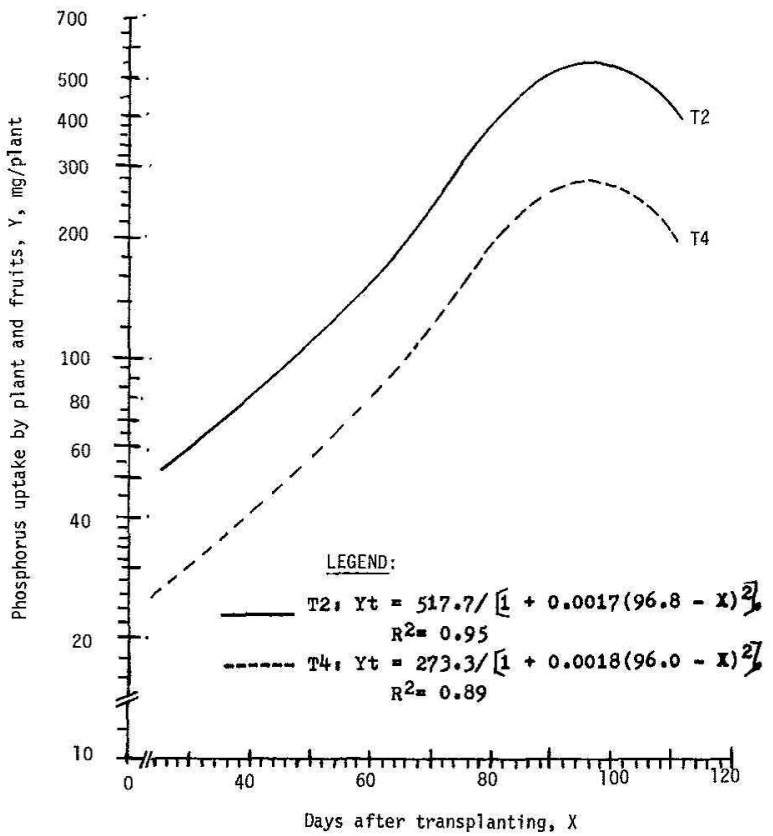

FIG. 3.-Phosphorus uptake by drip irrigated pepper plants in silver coated black plastic mulched plots. $\mathrm{T} 2=60 \% \mathrm{~N}$ via drip irrigation and $\mathrm{T} 4=$ banded nitrogen. Each observation is a mean of four observations.

\section{LITERATURE CITED}

1. Belle, H. S. and G. E. Wileox, 1985. Nitrogen fertilization and muskmelon growth, yield and nutrition. In: Drip/Triekle Irrigation in Action, Vol. I. Am. Soc. Agrie. Eng., St. Joseph, MI. 1:339-45.

2. Black, C. A., 1965. Methods of Soil Analysis II. Agronomy Monograph No. 9, Am. Soc. Agron., Madison, WI.

3. Goldherg, D., B. Gornat, and B. Bar, 1971. The distribution of roots, water and minerals as a result of trickle irrigation. $J$. Am. Soe. Hort. Sci. 96:645-48.

4. Goyal, M. R. and L. E. Rivera, 1985. Trickle irrigation seheduling of vegetables I $r$ : Drip/Triekle Irrigation in Action Vol. II. Am. Soc. Agrie. Fing., St. Joseph, MI 2:838-43. 


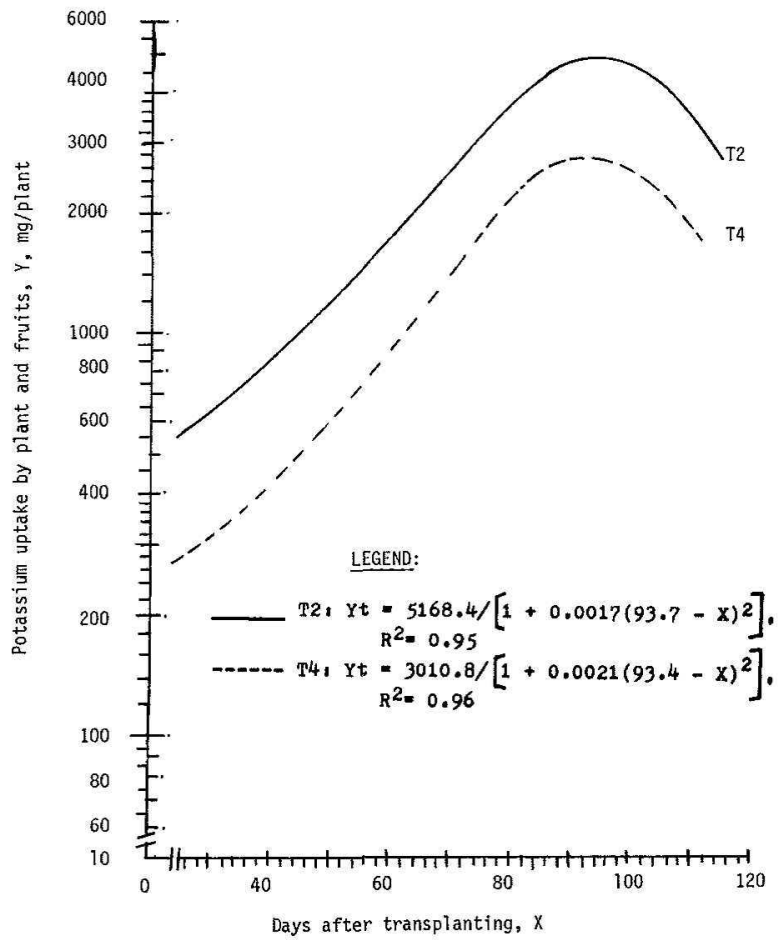

FIG. 4,-Potassium uptake by drip irzigated pepper plants in silver coated black plastic mulched plots. $\mathrm{T} 2=60 \% \mathrm{~N}$ via drip irrigation and $\mathrm{T} 4=$ banded nitrogen. Each observation is a mean of four observations.

5. C. L. Santiago and C. Chao de Báez, 1984. How plastic mulch types affect growth parameters of drip irrigated summer peppers. J. Agric. Univ. P. R. 68 (4):365-73.

6. Lorenz, O. A. and N. Maynard, 1980. Knott's Handbook for Vegetable Growers. John Wiley \& Sons, 2nd ed., page 390 .

7. Santiago, C. L. and M. R. Goyal, 1985. Nutrient uptake and solute movement in drip irrigated summer peppers. I. Agric. P. R. 69 (1):63-8. 
TABLE 2.-Effects of nitrogen levels on commercial yield of drip irrigated peppors

\begin{tabular}{|c|c|c|c|}
\hline \multirow[b]{2}{*}{ Nitrogen } & \multirow{2}{*}{$\begin{array}{l}\text { Method of } \\
\text { application }\end{array}$} & \multicolumn{2}{|c|}{ Conmercial yield } \\
\hline & & Plastic mulching & Nonmulching \\
\hline$k g / h a_{s}$ & & \multicolumn{2}{|c|}{$k g / h a$} \\
\hline $\begin{array}{l}\mathrm{T} 1=500 \\
\mathrm{~T} 2=300 \\
\mathrm{~T} 3=150 \\
\mathrm{~T} 4=500 \\
\mathrm{~T} 5=000\end{array}$ & $\begin{array}{l}\text { Fertigation } \\
\text { Fertigation } \\
\text { Fertigation } \\
\text { Banded } \\
\text { Control }\end{array}$ & $\begin{array}{l}46848.5 \\
51251.3 \\
43082.0 \\
31041.5 \\
20755.3\end{array}$ & $\begin{array}{l}26273.0 \\
34631.0 \\
27877.3 \\
25995.3 \\
14818.5\end{array}$ \\
\hline $\begin{array}{l}\text { Dumnett test }{ }^{2} \\
500 \\
000\end{array}$ & $\begin{array}{l}\text { Banded } \\
\text { Control }\end{array}$ & $\begin{array}{c}10200.26 \\
9666.5\end{array}$ & $\begin{array}{c}\text { NS } \\
9666.5\end{array}$ \\
\hline
\end{tabular}

IT1 $=500, \mathrm{~T} 2=300$ and $\mathrm{T} 3=150 \mathrm{~kg}$ of $\mathrm{N} / \mathrm{ha}$ applied via drip irrigation in 11 equal applieations on days $6,13,17,24,34,42,50,56,65,79,95$ after transplanting; $\mathrm{T} 4=250$ $\mathrm{kg}$ of $\mathrm{N} / \mathrm{ha}$ sidedressed on days 6 and 56 ; and $\mathrm{T} 5=0.0$ eontrol.

'In Dunnett's test, mean of treatments is compared with control at $5 \%$ level of significance. Mean of all treatments was compared with mean of control, and mean of fertigation treatments was compared with banded treatment. $\mathrm{NS}=$ non significant at $\mathrm{P}=0.05$. 